\title{
LAW, LANGUAGE AND LATIN AMERICAN CONSTITUTIONS
}

Joel Colón-Ríos*

Latin America has many languages and many constitutions. This article provides a general overview of the ways in which some constitutions of Latin American states relate to the multi-lingual context in which they operate.

Latin America has been described as the land of many languages as over 500 languages are spoken in the region, ${ }^{1}$ but it is also the land of many constitutions with more than 200 constitutions being adopted, or suffering extended revision, during the last two centuries. ${ }^{2}$ The topic of this short article is thus of immense proportions, and its objective will be to provide a very general overview of the ways in which several Latin American constitutions relate to the multi-lingual context in which they have been adopted. After providing a brief account of Latin American constitutional history in Part I, the article will then consider the relationship between language and constitutions in three different contexts: the creation of new constitutions, constitutional protection of language rights, and the process of making a constitution accessible to speakers of a language different from the one in which it was originally written.

Accordingly, Part II will examine the role of language and cultural diversity in the social and political processes that led to the adoption of the Bolivian Constitution of 2009, placing special emphasis on indigenous demands for the recognition of cultural and language rights, but also noting the ways in which these claims relate to other types of demands, such as social and economic ones.

* Lecturer, Faculty of Law, Victoria University of Wellington.

1 Luis Enrique López "Reaching the Unreached: Indigenous Intercultural Bilingual Education in Latin America" (background paper prepared for the Education for All Global Monitoring Report, 2010) at 3. According to some studies, the number could be around 700 languages. Some of these languages are spoken by only dozens of people and others, like the Quechua and Aymara, by millions. See Luis Enrique López and Inge Sichra "Intercultural Bilingual Education among Indigenous Peoples in Latin America" in J Cummins and N H Hornberger (eds) Encyclopedia of Language and Education (2nd ed, Springer Science+Business Media LLC, Boston, 2008) vol 5 at 295.

2 The text of most historic Latin American constitutions can be accessed at <www.cervantesvirtual.com/portal/Constituciones/constituciones.shtml>. 
Part III will explore the content and scope of the right to language in the Venezuelan Constitution of 1999, and assess its language rights provisions from a theoretical perspective. Finally, Part IV will describe some aspects of the process through which the Colombian Constitution of 1991, initially drafted in the Spanish language, was translated into seven indigenous languages.

\section{OF CONSTITUTIONS AND LANGUAGES}

The history of Latin American constitution-making can be divided into four main waves. ${ }^{3}$ The first one took place in the 19th century, when most Latin American countries became independent. This wave was characterised by constitutions, influenced by the American and French Revolutions that recognised basic civil and political rights and generally established republican forms of government unitary states. ${ }^{4}$ The second wave of constitution-making took place in the mid-20th century, and it was then constitutions began to recognise social and economic rights, starting with the Constitution of Mexico, adopted in 1917 and still in place after more than 600 amendments. The constitutions adopted during these first two waves stressed the idea of a single nationhood and the rare references they made to the presence of distinct cultures in their territories usually involved a mandate to "civilise" the indigenous populations. ${ }^{5}$

It is in the third and fourth waves that the multi-cultural and multi-lingual character of the region was able to make its way into constitutional law. During these waves, constitution-makers decided to alter the ways in which their countries described themselves to the world, moving beyond the idea of a single national culture, and gave constitutional recognition to cultural difference. The third wave took place in the late 20th century and included not only the adoption of new constitutions (Brazil 1988, Colombia 1991, or Ecuador 1998), but the re-establishment or revision of constitutions that had been suspended or adopted by military regimes (for example Chile revised the Constitution of 1980, created during the Pinochet regime, and Argentina's Constitution of 1853 was re-established as the supreme law of the country after the return to democratic rule). In addition to recognising new categories of rights (for example indigenous rights), constitutions adopted during this third wave in some cases explicitly recognised the pluri-cultural character of the societies in

3 There are, of course, other ways of framing these waves. The approach presented here is not intended as a definitive classification.

4 Brazil opted for a monarchy, and Argentina, Brazil, Mexico, and Venezuela established federal states.

5 See, for example, Constitution of Chile 1822, art 47(6), which states that it is a duty of the Congress "to procure the civilisation of the territory's Indians". These constitutions also operated in a context in which the language of the state was the one inherited from the ex-colonial power (in most cases Spain, with Portuguese colonialism in Brazil, and French colonialism in Haiti being the most notable exceptions). In some cases, the constitution itself established Spanish as the only official language (see, for example, Constitution of Venezuela 1961, art 6). 
which they existed, even though an emphasis was still made on the existence of a single nation under which minority cultures would be protected (for example Ecuador 1998, or Colombia 1991).

The fourth wave is still taking place, and it begun with the adoption of the Venezuelan Constitution in 1999, and probably reached its highest point with the adoption of the Bolivian Constitution in 2009. This wave has been characterised not only by the inclusion of traditionally marginalised groups in constitution-making processes, but by constitutions that seek to establish new forms of participatory democracy and are adopted in highly volatile and polarised political contexts. ${ }^{6}$ Moreover, some of these constitutions (for example Bolivia 2009, or Ecuador 2008) embraced the idea of pluri-nationality, thus recognising the existence of several nations within a single territory, rather than a single nation composed of different cultural minorities. ${ }^{7}$ As suggested in the introduction, this essay is primarily concerned with constitutions adopted during these last two waves of constitution-making, and more specifically with the constitutions of Bolivia, Venezuela, and Colombia.

\section{PROMOTING CHANGE IN A MULTI-LINGUAL CONTEXT: THE CASE OF BOLIVIA}

As with most Latin American countries, Bolivia operated with Spanish as the exclusive language of the State for the many centuries that followed colonisation. Also, like most countries in the region, Bolivia is ethnically diverse. In fact, Bolivia is widely recognised as the Latin American country with the strongest indigenous presence. The 2001 census showed that of out a population of over 9 million people, 62 percent identified themselves as indigenous and over 50 percent spoke an indigenous language. ${ }^{8}$ Nevertheless, until recently, Bolivia's legal system operated under the opposite premise. For example, the constitutions of 1878 and 1947 described Bolivia as a homogeneous nation and only granted citizenship, and therefore the capacity to exercise political rights (that is, voting and being elected for a public position), to those who could read and write in

6 One important distinction between the third and fourth waves is that while the third emphasised the recognition of language and cultural rights of indigenous groups, the fourth attempted to address some of the economic effects of the political and social marginalisation these groups suffered. In fact, part of the controversy surrounding this fourth wave of constitution-making was the explicit use of the constitutional text to alter the economic model, in particular the regulation of property rights.

7 The case of Ecuador is interesting in this respect since the Constitution of 1998 (which defines the Ecudorian state as "pluri-cultural"), instead of recognising indigenous groups as "nationalities" as demanded by the Confederation of Indigenous Nationalities of Ecuador, art 83 of the Constitution of 1998 (which defines the Ecuadorian state as "pluri-cultural"), established that indigenous peoples "define themselves as a nationalities". Article 1 of the Constitution of 2008, however, went further by describing the Ecuador as a "pluri-national".

8 Rita Cancino "El Mosaico de las Lenguas de Bolivia; Las Lenguas Indígenas de Bolivia - ¿Obstáculo o Herramienta en la Creación de la Nación de Bolivia?" (2008) 13 Diálogos Latinamericanos at 2. 
the Spanish language. The Constitution of 1878 also conditioned citizenship to owning certain amounts of land and to having an annual income not received from work as a domestic servant. ${ }^{9}$

The most commonly spoken languages in Bolivia are Spanish (spoken by the majority of the population, although in most cases as a second language) and Quechua, which is the mother tongue of more than 4 million people. ${ }^{10}$ In addition to Spanish and Quechua, other widely spoken languages include Aymara and Guaraní. This linguistic diversity was allowed, and to some extent promoted, with the purpose of facilitating evangelisation during the first years of colonisation, but by the creation of the republic in the 19th century, a policy directed at the creation of a strong nation-state, with a single language and culture, was firmly in place. ${ }^{11}$ For instance, at the beginning of the 20th century, schools were established in indigenous communities with the purpose of "civilising" natives and integrating them into the Bolivian nation through compulsory Spanish teaching. ${ }^{12}$ By the mid-century, however, it was recognised that, at least in certain communities, education in indigenous languages was necessary in order to achieve Spanish language literacy. ${ }^{13}$

Not surprisingly, the legal superiority of the Spanish language was only part of the wider economic and political exclusion that the indigenous population of Bolivia had suffered since colonisation. In fact, Bolivia is generally considered the poorest country in the South American continent, and 60 per cent of those Bolivians that consider themselves indigenous are markedly poorer than the rest of the population. ${ }^{14}$ Even in this context of economic and political exclusion,

9 Constitution of Bolivia 1878, art 33 and Constitution of Bolivia 1947, art 43. As a result of these requirements, from 1880 to 1951 the Bolivian electorate was around 3 per cent of the total population. See Nancy Grey Postero Now We Are Citizens: Indigenous Politics in Postmulticultural Bolivia (Stanford University Press, Stanford, 2007) at [33].

10 Cancino, above $\mathrm{n} 8$, at 4 .

11 María Cristina Quisbert Quispe and Roberto Choque Canqui "Derecho a la Lengua de los Pueblos AymaraQuechua en Bolivia" in El Derecho a la Lengua de los Pueblos Indígenas; XI Jornadas Lascasianas (Universidad Autónoma de México, 2003). This type of policy (that is, a policy directed at developing a sense of national identity through a common language and culture) has been adopted at some point by all modern nation states. See Alan Patten and Will Kymlicka "Introduction: Language Rights and Political Theory: Context, Issues, and Approaches" in Will Kymlicka and Alan Patten (eds) Language Rights and Political Theory (Oxford University Press, Oxford, 2003) at 37 [Patten and Kymlicka].

12 Quispe and Choque Canqui, ibid, at 113; Law of December 11th, 1905 (Bol).

13 Solange G Taylor "Intercultural and Bilingual Education in Bolivia: The Challenge of Ethnic Diversity and National Identity" (2004) Institutio de Investigaciones Socio Económicas No 01/04 at 8-10.

14 According to Gillette Hall and Harry Anthony Patrinos Indigenous People, Poverty and Human Development in Latin America: 1994-2004 (World Bank, 2005) 52 per cent of Bolivia's indigenous people live in conditions of extreme poverty. While extreme poverty rates began to fall for non-indigenous people between 1997 and 2002 (from 31 per cent to 27 per cent), they remained the same for the indigenous population (actually increasing from 65 per cent to 72 per cent in rural areas). Grey Postero, above n 9, at 3 . 
there were important attempts of resistance. ${ }^{15}$ These attempts, however, were no match for the organised military forces of the colonisers, several centuries of religious indoctrination, and of policies directed at displacing indigenous culture. ${ }^{16}$

The formal exclusion of the indigenous population started to change in the mid-20th century. The 1952 revolution extended political rights to those who could not read and write and introduced a set of economic measures (including an agrarian reform) in response to demands by political parties and indigenous groups, even though the constitution still resembled that of a mono-lingual and mono-cultural nation. While important forms of economic, political, and cultural marginalisation continued, by the 1990s the indigenous movement had become a powerful political force, demanding different forms of cultural and economic justice. ${ }^{17}$ The influence of indigenous organisations increased considerably after the administration of Gonzalo Sánchez de Lozada adopted a set of institutional changes in the mid 1990s. ${ }^{18}$ These changes occurred in a context of intense political pressure (which partly took the form of mass mobilisations) from indigenous groups who demanded attention to issues of indigenous rights. ${ }^{19}$

15 Ibid at 3-4. In addition to being forced to work in the silver mines, they were treated as savages, killed or forced into servitude, or displaced from their lands. Moreover, until 1874 an Indian tribute system (that at some moments constituted nearly half of the national budget) was in place. Communal property was made illegal shortly after independence, which gave way to the massive expropriation of indigenous lands.

16 The most famous insurrections were those led by Túpac Katari during the 18th century. Before his execution, Katari, an Aymara, promised to return "made into millions". During the 1970s, different indigenous organisations that struggled for agrarian reforms and cultural recognition took Katari's name (for example, Movimiento Revolucionario Túpac Katari de Liberación, Movimiento Indio Túpac Katari). See Grey Postero, above n 9, at 42-43; Donna Lee Van Cott "From Exclusion to Inclusion: Bolivia's 2002 Elections" (2003) 35 JLAS 751 at 760.

17 The struggle against the eradication of the coca leaf, in which coca growers were frequently portrayed as an ethnic movement, played an important part in the organisation of the indigenous movement. Van Cott, ibid, at 761-762.

18 In the early 1990s, the idea of convening a Constituent Assembly for the adoption of a new constitution, which would require government to be responsive to the needs of the great majorities of the population, started to gain force. Raquel Gutiérrez Aguilar and Dunia Mokrani "Una Reflexión sobre el Proceso Constituyente en Bolivia" (2006) Somos Sur <www.somossur.net>.

19 Grey Postero, above n 9, at 125. The most important of these mobilisations was the "Marcha por Territorio y Dignidad" ("March for Territory and Dignity") in 1990, in which indigenous groups came together to put forward demands for territory, and cultural and political rights. As a direct result of this manifestation, President Paz Zamora met with indigenous leaders and created seven indigenous territories by Presidential Decree. 
In terms of cultural recognition one of these changes took place through a constitutional amendment in 1994, which declared Bolivia a "multi-ethnical and multi-cultural" country, ${ }^{20}$ and also signalled a transformation in the country's approach to linguistic diversity: part of the implementation of this amendment took place six years later through a Presidential Decree that granted official status to thirty five indigenous languages. ${ }^{21}$ Over the next few years, a set of additional electoral reforms increased in the abilities of indigenous communities to participate in the process of decision-making at a local level, ${ }^{22}$ an agrarian reform instituted collective titling for indigenous territories, ${ }^{23}$ and the Educational Reform Law was adopted, promoting an "intercultural and bilingual" education based on "the socio-cultural heterogeneity of the country". ${ }^{24}$ According to art 9(2) of that law, education would either be monolingual in Spanish but with the study of an indigenous language, or bilingual with an indigenous language as the first language and Spanish as the second. ${ }^{25}$

But these changes, while positive in terms of cultural recognition and political participation, came accompanied by a set of economic measures that involved a wave of privatisations of state owned resources and an aggressive policy for the eradication of coca crop (which constituted an important part of the income of rural indigenous communities). Such measures continued during the late 1990s and early 21st century, where economic conditions worsened dramatically, particularly affecting the poor and the indigenous. In the year 2000, the administration of Hugo Banzer decided to privatise water services in Cochabamba, and water prices increased to a point that made the resource inaccessible to a great part of the population. ${ }^{26}$ Massive popular mobilisations resulted, with the indigenous movement playing an essential role, this time not under the banner of cultural and political recognition, but against a set of policies generally labelled as neoliberal. Interestingly, although many of the protesters were indigenous, these protests, unlike those in the 1990s which centred on indigenous issues, were done on behalf of the "Bolivian people". ${ }^{27}$

20 Constitution of Bolivia 1967 (as reformed in 1994, art 1). Article 6 was also reformed in order to include freedom from discrimination on the basis of language. Article 171 was reformed to include the right to language as a social, economic, and cultural right of indigenous communities, whose use and sustainable development was to be respected.

21 Decreto Supremo 25894 (2000).

22 Law of Popular Participation, Law 1551 (1994) (Bol).

23 Grey Postero, above n 9, at 5-6.

24 Law on Educational Reform, Law 1565 (1994) (Bol), art 5(1).

25 Ibid, art 9(2).

26 Van Cott, above n 16, at 769.

27 Grey Postero, above n 9, at 4. 
The popular pressure on the government during the Water War of 2000 was so strong that the United States company that bought the water concession left the country, and a wave of parallel protests by coca growers (under the leadership of the Evo Morales, a well known Aymara labour leader) ensued. The elections of 2002 took place in this volatile political environment, and two indigenous peoples' parties, running as the Movimiento al Socialismo (MAS) party, surprised the country by obtaining 27 per cent of the vote and winning over 40 seats in the National Congress; in the previous national election all indigenous parties combined received an all time high of 4.6 per cent of the vote). In order to accommodate the new linguistic diversity in Congress, interpreters were hired by the government for the first time in history to provide simultaneous translations between Spanish, Aymara, Quechua, and Guaraní. ${ }^{28}$ Shortly after the election, through which Sánchez de Lozada returned to the Presidency, ${ }^{29}$ the government proposed to allow foreign corporations to export natural gas from Bolivia. ${ }^{30}$

The demonstrations against this proposal were initiated by poor urban Aymara Indians. Protesters demanded the nationalisation of transnational gas concessions, an end to neoliberal policies, and a call for a Constituent Assembly to re-write the country's constitution. This last proposal had been a demand of the indigenous movement since the 1990s, increased after the Water War of 2000, and by the Gas War of 2002. It had become one of the principal demands of popular movements in Bolivia. After six weeks of violence and popular mobilisations, President Sánchez de Lozada abandoned the country. Vice-President Carlos Mesa assumed the Presidency and promised a set of constitutional changes that involved the inclusion of mechanisms of direct democracy, such as the referendum and the popular legislative initiative, ${ }^{31}$ a provision allowing for the convocation of a Constituent Assembly, ${ }^{32}$ and a referendum on gas export policies. ${ }^{33}$ Popular mobilisations and strikes continued for months (while a date for the convocation of the Constituent Assembly had not been set by Parliament), and President Mesa had to resign from office and new elections calling in 2005. In an unprecedented turn of events, Evo Morales, the Aymaran leader of the MAS, was elected President with 54 per cent of the vote.

The Constituent Assembly was convened in 2006, and the MAS obtained 53 per cent of the delegates selected in a special election. Silvia Lazarte, a Quechua woman, was elected President of the Assembly. The process of drafting a new constitution was a complex and controversial one, in

28 Van Cott, above n 16, at 752-753.

29 From 1997 to 2002 the Presidency was occupied first by Hugo Banzer and then by Jorge Quiroga.

30 Grey Postero, above n 9, at 2.

31 Constitution of Bolivia 1967, art 4 (as reformed by Law 2631, 20 February 2004).

32 Constitution of Bolivia 1967, art 232 (as reformed by Law 2631, 20 February 2004).

33 The referendum was held in 2004. 
which the scope of the power of the assembly and the internal voting rules lead to serious political conflicts. ${ }^{34}$ The linguistic diversity of the delegates also became an issue. For example, the absence of translators during the first days of deliberations caused unfortunate incidents in which the still very much present racial prejudices against indigenous peoples resurfaced. ${ }^{35}$ Eventually, a system of simultaneous translations between Quechua, Aymara, Guaraní, and Spanish was established, although the first language of several delegates was not one of those. ${ }^{36}$ In a tense political climate, dominated by confrontations between MAS supporters and the opposition, the final text of the Constitution was adopted in December 2007. It was ratified by more than 60 per cent of the electorate in a referendum held on January 2009.

It should come as no surprise that the content of that constitution differs in important ways from any previous legal document in the country. The Political Constitution of 2009 described the Bolivian state as "pluri-national" (in contrast with the previous emphasis on multi-culturalism and on the co-existence of different ethnicities), and established as one of its goals the promotion of the self-determination of all the peoples of Bolivia. ${ }^{37}$ In attempting to achieve that purpose, it states that Bolivia will exist in political, economic, legal, cultural, and linguistic pluralism, and that the selfdetermination of the peoples of Bolivia will include the right to autonomy, self-government, and the recognition of their institutions and territories. ${ }^{38}$ Moreover, it not only recognises 38 official languages (including Spanish) ${ }^{39}$ but establishes as a pre-requisite for occupying any public position the knowledge of at least two official languages. ${ }^{40}$ It also mandates an inter-cultural and plurilingual education in all levels of the education system, states that "cultural diversity is the essential basis" of the pluri-national state, and sees inter-culturality (inter-culturalidad), understood not only as recognising cultural difference but as involving the promotion of relations between different

34 There is no space to consider these conflicts here. See Jorge Lazarte "La Asamblea Constituyente de Bolivia: De la Oportunidad a la Amenaza" (2008) Nuevo Mundo Mundos Nuevo <nuevomundo.revues.org/42663>; Reuben Martínez Dalmau El Proceso Constituyente Boliviano (20062008) en el Marco del Nuevo Constitucionalismo Latinoamericano (Editorial Enlace, La Paz, 2008).

35 "Constituyente: El País Muestra todos sus Rostros" (2007) El Deber <www.eldeber.com.bo>.

36 "Asamblea Constituyente ya Tiene Norma para Sesionar" (2006) El Mundo <www.elmundo.com.bo>.

37 Constitution of Bolivia 2009, Preamble. See "Propuesta para la Nueva Constitución Política del Estado: Por un Estado Plurinacional y la Autodeterminación de los Pueblos y Naciones Indígenas, Originarias y Campesinas" (2006) Constituyentes Oberana <www.constituyentesoberana.org>.

39 Ibid, art 5.

40 Ibid, arts 234 and 144. 
cultures as "an instrument for the cohesion and the harmonic and balanced co-existence between all peoples and nations". 41

There is no guarantee that this new constitutional regime will succeed in abolishing the social and economic marginalisation suffered by the great majority of the Bolivian population, but there is no doubt that the new Political Constitution respects and promotes the country's diversity in important ways. However, as this brief account shows, even though language and cultural claims have historically played an important part of the indigenous movement's political programme, at different times claims of economic justice that went beyond claims for cultural recognition assumed a central role. In that respect, while the officialisation of indigenous languages, the constitutional description of Bolivia as a multi-cultural nation, and the Law of Popular Participation, were not enough to put an end to economic and political exclusion, they provided the indigenous movement with a higher capacity of political organisation and a social presence that, at least in part, made possible the adoption of the Political Constitution of 2009.

\section{LANGUAGE RIGHTS IN THE CONSTITUTION OF THE BOLIVARIAN REPUBLIC OF VENEZUELA}

As noted above, the Bolivian Political Constitution of 2009 recognised 38 official languages. Some of those languages, like Spanish, Quechua, and Aymara, were not minority languages, but languages spoken by millions. Some of the other languages recognised as official, however, have only a handful of speakers. What does it mean to recognise a minority language as an official language? This section of the paper will explore that question through an examination of the language rights provisions of the Venezuelan Constitution of 1999. That constitution operates in a context in which Spanish is the first language of the great majority of the population but in which several indigenous groups have their own languages. The section will begin by briefly considering different conceptions of language rights, ${ }^{42}$ and it will then provide a description of the social and political context in which the Constitution of 1999 was adopted, and examine its language rights provisions in light of the different conceptions mentioned above.

One common way of conceptualising language rights is through a distinction between toleranceoriented and promotion-oriented approaches The former gives linguistic minorities "leeway to use their language in those domains where not the authorities, but the citizens themselves become active" $^{43}$ (for example founding newspapers, running business establishments and talking over the

41 Ibid, arts 78 and 98.

42 The discussion of these conceptions relies heavily on Kymlicka and Patten's essay in Language Rights and Political Theory, above n 11, as well as some of the other essays contained in that volume.

43 Heinz Kloss "Language Rights and Immigrant Groups" (1971) 5 IMR 250 at 259-260. 
phone and in the streets). ${ }^{44}$ Under that approach, language rights are seen as capable of protection through basic liberal freedoms. For example, the right to freedom of speech would be seen as enough to protect the right to choose one's language of expression in social contexts, and the right to privacy as giving people the ability to choose the language to be used at home. ${ }^{45}$ A promotionoriented approach, in contrast, would mandate the state to actively protect minority languages and require the use of certain languages by public institutions. ${ }^{46}$ According to Rubio Marín, the "most characteristic sign of such a regime is the express recognition of a certain language or, eventually, several languages as the official language(s) of the state". ${ }^{47}$ Language rights of this kind would give individuals the ability to use a particular language to communicate with (and in) public institutions (for example courts, legislatures and public schools). ${ }^{48}$

A differing conception, which is based on a critique of the tolerance versus promotion dichotomy, advances a further distinction. ${ }^{49} \mathrm{~A}$ country's language policy can be characterised by a norm-and-accommodation (or an instrumental) approach to language rights: the language of the majority will be used in all public institutions, but special accommodations, such as translators and the availability of education programs to learn the majority language, will be made. ${ }^{50}$ An alternative would be the adoption of a non-instrumental approach in which certain languages, although usually not every single language spoken in a particular territory are recognised as official, and speakers of those languages are guaranteed certain rights. As Patten and Kymlicka have explained, "this approach typically involves a degree of equality between the different languages that are selected for official status". ${ }^{51}$ In contrast to the norm-and-accommodation model, the idea here is that the enjoyment of language rights does not depend on the inability of a person to communicate in the majority's language: even someone who is fluent in the majority's language would thus be granted the right to interact with the State in her own native tongue.

In other words, the non-instrumental view of language rights involves a public commitment "to help a certain collectivity achieve the goal of protecting its language", and to recognise rights that

\footnotetext{
44 Ibid at 260.

45 Ruth Rubio-Marín "Language Rights: Exploring the Competing Rationales" in Kymlicka and Patten, above n 11 , at 54

46 Kymlicka and Patten, above n 11, at 26.

47 Rubio-Marín, above n 45, at 55.

48 Kymlicka and Patten, above n 11, at 26-27.

49 For the critique, see Rubio-Marín, above n 45

50 Kymlicka and Patten, above n 11, at 28.

51 Ibid.
} 
would allow a language minority to avoid "the trade-off between state citizenship and cultural identity by ensuring that its speakers can live in their language in every relevant sphere, including the public sphere". ${ }^{52}$ This conception tends to see language rights as involving the recognition of the speakers of a particular language as a nation or people. ${ }^{53}$ In that respect, non-instrumental language rights are always collective rights: they focus on the cultural dimension of language, which, as Rubio-Marín insists, is only meaningful as a communal experience. ${ }^{54}$ This last point is in a way connected to a further distinction: language rights as based on personality or territoriality. Under the first approach, citizens enjoy the same set of language rights such as the right to obtain public services in their first -official- language, regardless of where they are; under the second approach, the exercise of particular language rights depends on where the speaker is located, usually in the community where the language is spoken. ${ }^{55}$ Having explored several ways of organising a language rights regime, the next subsection will look at the Venezuelan constitution through the lens of the previously discussed options and distinctions.

\section{A Venezuela}

When Hugo Chávez won the 1998 presidential elections in Venezuela it was clear that part of his political program included the adoption of a new National Constitution. Until 1999, Venezuela's constitutional regime operated under a fundamental law that resembled that of a typical liberal democracy. ${ }^{56}$ Adopted by the then newly elected Congress (which transformed itself into a constitution-making body), the Constitution of 1961 was the direct result of Punto Fijo, an agreement brought to life by the country's major political parties and whose main objective was to create a stable democracy and to prevent a return to military rule. By the 1980s, however, many critics claimed that instead of being a democracy, Venezuela had transformed into a "partidocracia"

52 Rubio-Marín, above n 45, at 57.

53 Kymlicka and Patten, above n 11, at 28.

54 Rubio-Marín, above n 45, at 57. On this point, see also Leslie Green "Are Language Rights Fundamental?" (1987) 25 OHLJ 639.

55 Kymlicka and Patten, above n 11, at 29.

56 In fact, for many years after 1961 Venezuela was considered an exemplary democracy in a region characterised by authoritarianism and dictatorship. This is notwithstanding the fact that the period following the adoption of the 1961 Constitution was characterised by episodes of political repression, particularly against the left. See Edgardo Lander "Izquierda y Populismo: Alternativas al Neoliberalismo in Venezuela" in Cesar Rodríguez Garavito, Patrick S Barret and Daniel Chavez (eds) La Nueva Izquierda en América Latina: Sus Orígenes y Trayectoria Futura (Grupo Editorial Norma, Bogotá, 2005) at 99. Some authors maintain that the Constitution of 1961 was an adequate constitution which was at least partly responsible for the stability of Venezuelan democracy and, therefore, not in need of replacement. See Miriam Kornblith "The Politics of Constitution-Making: Constitutions and Democracy in Venezuela" (1991) 23 JLAS 61 at 87-88. 
("partyarchy"), in which the two leading political parties alternated political power. ${ }^{57}$ The perception of unfairness in the political system, combined with the economic decline of the $80 \mathrm{~s}$ and 1990s that impoverished great masses of Venezuelans (which contrasted with the oil bonanza of the 1970s) and the widespread belief that political elites were illegally enriching themselves with oil revenues, were some of the factors that precipitated Chávez's electoral victory and the convening of a Constituent Assembly to draft a constitution that would create a new order "based on a social and participatory conception of democracy". 58

Unlike in Bolivia, as a result of the small size of the indigenous population of Venezuela, indigenous peoples did not play a central role in the push for constitutional change in the country. However, indigenous organisations were active during the process that preceded the convocation of the Constituent Assembly, establishing important links with other social movements. ${ }^{59}$ For example, workshops on constitutional reform and human rights were held through the states of Maracaibo and Amazonas in February and March of $1999 .{ }^{60}$ Moreover, the Consejo Nacional Indio de Venezuela ("National Indian Council of Venezuela or CONIVE"), after being provided with office space and technical support by the government, encouraged indigenous organisations to generate and discuss proposals about the content of the new constitution. ${ }^{61}$ In March 1999, the government designated three seats for indigenous delegates in the Constituent Assembly, out of a total of $131 .^{62}$

The Constitution drafted by the Constituent Assembly was ratified in a referendum in December 1999. Its preamble establishes as part of its objectives the creation of a democratic, participatory, multi-ethnic and multi-cultural society. It includes new mechanisms of participatory democracy and,

57 Michael Coppedge "Venezuela: Popular Sovereignty versus Liberal Democracy" in Jorge I Domínguez and Michael Shifter (eds) Constructing Democratic Governance (2nd ed, Johns Hopkins University Press, Baltimore, 2001) at 171 .

58 Ibid at 173. See also Lander, above n 56. The Constituent Assembly was convened through a referendum (which was held in April 1999, with 92 per cent of the participating electors voting in favor).

59 See Donna Lee Van Cott "Andean Indigenous Movements and Constitutional Transformation: Venezuela in Comparative Perspective" (2003) 30 LAP 49 at 55.

60 Ibid.

61 Ibid.

62 Ibid at 56. In the election of the delegates to the Constituent Assembly, two additional indigenous activists won seats. 
unlike the Constitution of $1961,{ }^{63}$ recognises a generous catalogue of indigenous rights, language rights included. ${ }^{64}$ For Venezuela's constitutional system, whose historical treatment of its indigenous population compares negatively with other countries in the region, this was an unprecedented development. ${ }^{65}$ In 2000, it was estimated that Venezuela's indigenous population represented around 2 per cent of the total population (511,784 persons out of 25 million), ${ }^{66}$ even though other studies suggest that the number might be higher. ${ }^{67}$ This population is comprised of around 30 groups (with 14 of those groups having more than 4,000 members and some having less than 10), mainly settled in ten states. ${ }^{68}$ Around 84 per cent of the members of those groups speak their group's indigenous language, and around 50 per cent also speak Spanish. ${ }^{69}$ In what follows, I will focus on those provisions of the new Constitution that are directly related to language. I will not make reference to other provisions that explicitly recognise other social, political and economic rights of indigenous peoples. I will then examine them in light of the different approaches to language rights discussed above.

Article 9 of the Constitution establishes Spanish as the official language of the Republic, and states that "indigenous languages will also be of official use for indigenous peoples and should be respected in the Republic's entire territory, since they constitute part of the cultural heritage of the Nation and of humanity". Article 119 states that the government will recognise the existence of

63 The only provision related to indigenous rights contained in the Constitution of Venezuela 1961 was the following (art 77):

The State will promote the improved living conditions of the peasant population. The law will establish a regime of exception that requires the protection of the indigenous communities and their progressive incorporation to the life of the Nation.

64 The Venezuelan Constitution of 1999 has also been subject to many critiques, which underscore the wide powers granted to the executive. See for example Renata Segura and Ana María Bejarano "!Ni una Asamblea más sin Nosotros! Exclusion, Inclusion, and the Politics of Constitution-Making in the Andes" (2004) 11 Constellations 217.

65 Van Cott, above n 59. See also Bartolomé Clavero "El Derecho Indígena entre el Derecho Constitucional y el Derecho Internacional, Venezuela y Awas Tingi" (2004) 39 Revista IIDH 258.

66 Luisa Pérez de Borgo "Educación Superior Indígena en Venezuela: Una Aproximación" (paper prepared for UNESCO-IESALC and the Venezuelan Ministry of Superior Education, December 2004) at 5.

67 For example, Dalita Rivero, Silvia Vidal and Manuel Bazó "Enfoque de Lenguas Indígenas: Hacia un Sistema Integral de Calidad de Vida y Salud" (2009) Ministerio de Salud y Desarrollo Social \& Agencia de Cooperación Alemana <http://190.39.165.96/gsdl/collect/document/index/assoc/HASH4168.dir/doc.pdf>.

68 The exact number of indigenous groups living in Venezuelan territory is not known. For example, the 1992 Census states that there are 28 indigenous groups. The Law of Demarcation and Guarantee of the Habitat and Lands of the Indigenous Peoples (12 January 2001) (Ven) refers to the existence of 35. It leaves the door open for the identification of new groups in the future (art 14).

69 Pérez de Borgo, above n 66. 
indigenous communities and peoples, their social, political, and economic organisation, their cultures, customs ("usos y costumbres"), languages and religion, as well as their habitat and original rights over the lands that they occupy since time immemorial ("ancestral y tradicionalmente") and that are necessary for the development and protection ("para dessarrollar y garantizar") of their ways of life. Article 121 establishes that indigenous peoples have the right to maintain and develop their ethnic and cultural identity, world views ("cosmovision"), values, spirituality, and sacred and religious places ("lugares sagrados y de culto"). That same article adds that the state will "promote the appreciation and dissemination ("la valoración y diffusion") of indigenous peoples' cultural manifestations", and that indigenous peoples have a right to "an education regime of a bilingual and intercultural character, one that pays attention to their socio cultural particularities, values, and traditions".

When these provisions are examined from the perspective of the toleration versus promotion dichotomy, they seem to fall upon the latter's end of the spectrum, as they go well beyond tolerating the existence of minority languages or guaranteeing their expression through traditional liberal protections. However, at least on a literal reading, the constitution does not recognise indigenous languages as official languages of the state. It thus sanctions the legal inequality between Spanish and the various indigenous languages. Nevertheless, at the same time, the Constitution gives indigenous languages an official character that rests on a conception that sits somewhere between the territorial and personal approaches. ${ }^{70}$ That is to say, art 9 recognises indigenous languages as official for indigenous peoples, which seems to point towards a territorial conception given the reality that speakers of indigenous languages are generally located in specific regions of Venezuela, but at the same time mandates that they are to be respected throughout the entire territory of the Republic. Although the provision is clear that indigenous languages will not have the same legal status as Spanish, this reference to respect suggests that, even outside certain regions, indigenous languages will be treated in some special way, as compared, for example, to a foreign language.

The idea of treating indigenous languages with respect through the entire territory of the country, together with the conception of indigenous languages as cultural heritage of the nation and of humanity, has a strongly non-instrumental bent. ${ }^{71}$ It does not seem to be primarily concerned with removing particular disadvantages that might result from not speaking the language of the majority, but with helping indigenous groups in preserving the existence of their language. The

70 Given the size of Venezuela's indigenous population and the great number of languages spoken by the various indigenous groups, this approach does not seem objectionable.

71 Some provisions of the Constitution of Venezuela, however, exhibit a norm-and-accommodation or instrumental approach. For example, art 49(3) establishes that everyone has a right to be heard in any judicial or administrative process and those "who do not speak Spanish, or are not able to communicate verbally, have a right to an interpreter". 
reference in art 119 and art 121 to recognising indigenous languages and cultures with the objective of promoting the development and protection of indigenous peoples' ways of life is also relevant from the non-instrumental point of view: it underscores the cultural dimensions of language and its connections to the status of the indigenous groups as peoples. The establishment of an education regime of a bilingual and inter-cultural character can also be seen as a way of preserving indigenous languages and of allowing for their reproduction; and for the reproduction of indigenous cultures, over time. ${ }^{72}$ Its inter-cultural character also emphasises the need to procure the cultural exchange and co-existence of different groups (indigenous and non-indigenous) that share the same territory.

Although the language rights and protections included in the Venezuelan Constitution of 1999 in some ways fall short of the previously mentioned provisions of the Bolivian Constitution of 2009, given the size of indigenous communities in Venezuela and the particular history of the country, they are definitely a positive development. They contrast with the infamous provision of the Venezuelan Constitution of 1904 which, after establishing that the number of representatives to be elected to the lower house of the legislature would depend on the number of citizens living in the relevant geographical locality, stated "indigenous in a savage state will not be counted as part of the population" ("No se computarán en la base de población los indígenas que vivan en estado salvaje"). ${ }^{73}$ Since the protections guaranteed to the indigenous peoples of Venezuela were unprecedented in that country, it is not surprising that they encountered resistance. For example, within the Constituent Assembly, there was strong opposition to the use of the term "indigenous peoples" (emphasis added), which was seen by some as opening the door for future claims of secession. ${ }^{74}$ A compromise was finally reached on that point through a provision that stated that the term "people" was not to be understood as it is used in international law. ${ }^{75}$

72 According to Presidential Decree No 1796 of 27 May 2002, all public and private schools located in indigenous territories must use indigenous languages. Moreover, according to art 79 of the Ley Orgánica de Pueblos y Comunidades Indígenas (Organic Law of Indigenous Communities and Peoples), Gaceta Oficial No 38.344, 27 December 2005), which implements various indigenous rights contained in the Constitution, in a bilingual and intercultural educational regime teaching must occur in the relevant indigenous language but Spanish will also be taught on a gradual basis.

73 Constitution of Venezuela 1904, art 33.

74 The concern with maintaining the territorial integrity of the state has always been present in discussions about indigenous rights. For example, even the Constitution of Ecuador 2008, which in many ways goes further than the Venezuelan Constitution on indigenous issues by affirming that indigenous communities are "nationalities", states that they form part of the indivisible (único e indivisible) Ecuadorian state (art 56).

75 Constitution of Venezuela 1999, art 126. This type of provision is also included in the International Labour Organisation's Convention Concerning Indigenous and Tribal People in Independent Countries (adopted 27 June 1989, entered into force 5 September 1991), art 1(3): "the use of the term 'peoples' in this Convention shall not be construed as having any implications as regards the rights which may attach to the term under international law". 


\section{TRANSLATING THE COLOMBIAN CONSTITUTION OF 1991: BRIDGING DIFFERENT WORLDS}

The Colombian Constituent Assembly of 1991 was convened in the climate of violence and political crisis present in the country for an important part of the 20th century, and still present in the 21st. By the early 1990s, an armed conflict that involved the military, guerrillas, paramilitary groups and drug cartels had become one of the principal components of the Colombian political landscape. Moreover, as in Venezuela, the country's political system was perceived as hostile to the incorporation of new political movements that represented interests different from those traditionally advanced by the Liberal and Conservative parties. ${ }^{76}$ In 1990, a student movement led a campaign in favour of convening an assembly that would draft a new constitution. This movement was responsible for the introduction of a "seventh ballot" ("séptima papeleta") in the 1990 elections that allowed the electors to express whether they favored the convocation of an assembly for the modification of the Constitution of $1886 .{ }^{77}$ After a positive vote in a referendum, the Constituent Assembly, whose delegates were not limited to members of the traditional parties but also included representatives from social movements, ex-guerrilla group members, and indigenous groups was convened in 1991 and a new constitution was produced. ${ }^{78}$

The 1991 Constitution has been widely celebrated since its adoption, and it included many of the proposals rejected by previous governments (such as the establishment of a Constitutional Court), mechanisms for the protection of social and economic rights, and the recognition of indigenous rights (including special rights to political participation and authority over their territories). ${ }^{79}$ In terms of language rights, it establishes Spanish as the official language of the country but, like the Venezuelan Constitution of 1999, establishes that indigenous languages will be official in "their territories". ${ }^{80}$ Moreover, it mandates a bilingual education in those communities

76 For a discussion, see César Rodríguez Garavito "La Nueva Izquierda Colombiana: Orígenes, Características y Perspectivas" in César Rodríguez Garavito, Patrick S Barret and Daniel Chavez (eds) La Nueva Izquierda en América Latina: Sus Orígenes y Trayectoria Futura (Grupo Editorial Norma, Bogotá, 2005).

77 Segura and Bejarano, above n 64.

78 Ibid.

79 The Constitution of Colombia 1991 recognises the ethnical and cultural diversity of Colombia (art 7), designates special seats for indigenous communities in the Senate (art 171), and recognises the authority of indigenous peoples within their territories as long as they are not contrary to the law and the constitution (art 246). For a discussion of the practical effects of the recognition of these rights, see Guillermo Padilla "La Ley y los Pueblos Indígenas de Colombia" (1999) 1 JLAA 78; Frank Semper "Los Derechos de los Pueblos Indígenas de Colombia en la Jurisprudencia Constitucional" (2006) Anuario de Derecho Constitucional Latinoamericano 761.

80 Constitution of Colombia 1991, art 10. 
with their own "linguistic traditions". ${ }^{81}$ According to the 2005 census, Colombia has more than 80 distinct indigenous communities, with a total population of 1,392,623 (representing 3.43 per cent of the total population). ${ }^{82}$ Three of these groups (the Wayúu, Paez and Emberá) have more than 50,000 members, while at least thirty of them have fewer than 500 members. Within these groups, there are more than 60 different languages. ${ }^{83}$

These groups had been involved in struggles about land for most of the 20th century, and by the 1980s they reached an important level of political organisation, creating the Organización Nacional Indígena Colombiana ("National Colombian Indigenous Organization", or ONIC) in 1982. ${ }^{84}$ According to many accounts, although the country's cultural diversity was a known fact, when the Constituent Assembly was convened in 1990, and the representatives of the indigenous communities were seen in their traditional outfits, expressing in their own languages about their religions and customs, many Colombians for the first time became truly aware of the existence of an indigenous population in their country. ${ }^{85}$ As noted above, the Colombian Constitution of 1991 came a long way in matters of indigenous rights, particularly when compared with the previous Constitution of 1886 . However, instead of examining the events that led to the adoption of this Constitution or exploring its content, this section will briefly consider some aspects of the process through which the constitution, originally written in the Spanish language, was translated into seven indigenous languages as well as its reception by the indigenous communities.

The translation of the Constitution was formally initiated by the government of President César Gaviria Trujillo, who created a centre with the mandate of disseminating the new constitutional text to the widest extent possible. ${ }^{86}$ The centre commissioned the translation of the constitutional text to the Centro Colombiano de Estudios de Lenguas Aborígenes de la Universidad de los Andes de Bogotá (Colombian Centre for the Study of Aboriginal Languages at the University of Los Andes in Bogotá, or CCELA). The academics at CCELA (many of them indigenous) had for years been doing research on the grammar and structure of several indigenous languages. In this respect, the

81 Ibid.

82 "Colombia Una Nación Multicultural: Su Diversidad Etnica" (Departamento Administrativo Nacional de Estadística, 2007) at 37. There are different estimates of both the number of indigenous groups and their members. See Sr Rodolfo Stavenhagen Informe del Relator Especial sobre la Situación de los Derechos Humanos y las Libertades Fundamentales de los Indígenas E/CN.4/2005/88/Add.2 (2004).

83 "Colombia: Una Nación Multicultural: Su Diversidad Etnica", ibid at 9.

84 Sandra Liliana Oróstegui Durán "Traducción de la Constitución Colombiana de 1991 a Siete Lenguas Vernáculas" (2008) 10 Reflexión Política 164 at 166.

85 Ibid at 167; Jon Landaburu "Historia de la Traducción de la Constitución de Colombia a Siete Lenguas Indígenas" (1997) 22 Amerindia 109 at 111.

86 Landaburu, ibid. 
translation took place at a time of intense scholarly collaboration between indigenous academics and linguists. ${ }^{87}$ However, as Jon Landaburu (one of the academics at CCELA) explains, translating the constitution "represented a totally new task and a very risky challenge", 88 as it required finding indigenous expressions equivalent to legal concepts developed in a written, urban, and European tradition.

The project progressed in different stages, which involved more than one year of work by indigenous researchers, discussions among translators, linguists and jurists, meetings in indigenous communities in which the nature of the project and possible translations of legal concepts were discussed, and the final approval of the translation by the community. ${ }^{89}$ The translations themselves were made by a combination of indigenous and non-indigenous academics, as well as non-academic community members that had proficiency in the indigenous language and Spanish. ${ }^{90}$ Although CCELA originally proposed to translate the constitution into 12 indigenous languages, this number had to be reduced, mainly as a result of financial constraints and the availability of indigenous linguists, to seven. The chosen languages were selected on the basis of the willingness of the indigenous community to participate in the project, the size of the indigenous group, and the availability of indigenous linguists. ${ }^{91}$ Also, because of the length of the Constitution of 1991 (which has 380 articles and 60 transitional articles), it was determined that only those articles that referred to fundamental and indigenous rights (40 articles) would be translated. ${ }^{92}$

Although the Constitution of 1991 recognised the pluri-cultural character of the country and to a certain extent included many of the historical demands of the indigenous population, the academics at CCELA were very aware that it was a document in many ways alien to the indigenous. ${ }^{93}$ The idea was thus not to attempt to make the constitution fit within indigenous peoples' worldviews and cultures, but "to open a window towards the conceptions of political order, the hierarchies, and

87 Kay B Warren and Jean E Jackson Indigenous Movements, Self-Representation, and the State in Latin America (University of Texas Press, Texas, 2003) at 59.

Landaburu, above n 85

89 Ibid at 113.

90 José Narciso Jamioy Muchavisoy "Experiencias Vividas en la Traducción de Apartes de la Constitución Política de Colombia a la Lengua Kamëntsa" (1997) 22 Amerindia 119 at 121.

91 Landaburu, above n 85, at 112-113. These were Wayuu (130,000 speakers), Nasa (100,000 speakers), Guambiano (15,000 speakers), Arhuaco or Iktn (15,000 speakers), Ingano (15,000 speakers), Kamsá or Kamëntsa (5,000 speakers), Cubeo (5,000 speakers).

92 Ibid at 113

93 Rubiel Zalabata Torres "La Traducción Interlingual: Un Acercamiento entre Dos Universos. La Experiencia de Traducción de Apartes de la Constitución Política de Colombia del Año 1991, del Español a la Lengua Iktn de la Siera Nevada de Santa Marta, en Colombia" (1997) 22 Amerindia 133 at 135. 
regime of Colombian society". ${ }^{94}$ In that sense, as one of the academics from CCELA has expressed, the constitution was not presented to indigenous communities as their own law, but as "a Higher or Primary Law of the whites that recognised certain rights of indigenous peoples that should be known to them as useful tools for the defence and protection of culture". 95 The reaction of indigenous communities (and within indigenous communities) to the translation project varied in interesting ways.

For example, many Kamsá expressed that translating the constitution represented a dangerous endeavour, as the project could be used by the Colombian state to impose its laws to a people that had for a long time enjoyed a condition of relative political autonomy. ${ }^{96}$ Interestingly, they were especially concerned with the word "political" (as in "Constitución Política"), which was seen as referring to "an activity alien to the indigenous", associated with lies and broken promises. ${ }^{97}$ In contrast, the Nasa, who had an opportunity to participate in the Constituent Assembly through two delegates, mostly interpreted the project as an additional step towards their cultural recognition. ${ }^{98}$ Moreover, each indigenous community decided to translate key legal concepts in a way that reflected not only their culture and particular history, but also their relationship to the Colombian State or to the "whites". Those groups that, particularly as a result of their geographical location, had historically had more contact with the Colombian state (and most of the time "contact" meant submission and oppression), largely approached the Constitution as a document to be obeyed.

For example, the Guambianos translated the word "Constitution" as "wamwam trek kontrei isua ponk", which literally means, "the highest written word to be obeyed", 99 and the Inga as "achka lachag Panga Kuna", meaning "the law that guides the other laws". ${ }^{100}$ On the other hand, the groups that had been historically isolated tended to make more use of metaphors that referred to their own cultural understanding. For example, the Cubeo translated the word "Constitution" as "au'hokiiki tukúbo", which means "the book of the tree that nourishes life". ${ }^{101}$ The Paeces, which have a long history of resistance against colonisation, also produced a translation full of metaphors

\author{
94 Ibid at 136. \\ 95 Ibid at 135. \\ 96 Jamioy Muchavisoy, above n 90, at 120 . \\ 97 Ibid \\ 98 Oróstegui Durán, above n 84, at 170. \\ 99 In Spanish, "la palabra mayor escrita para ser cumplida". \\ 100 In Spanish, "la ley que guía las otras leyes". Oróstegui Durán, above n 84, at 172. \\ 101 In Spanish, "libro del árbol de alimento para la vida". Oróstegui Durán, ibid at 173.
}


and translated "Constitution" as "Ikahsa Ec Ne'hwe's", which means, the "highest leaf of power"102 The Wayuu, also historically isolated from the Colombian state, opted for a different route that seemed to reflect a sense of distance to the document. Instead of attempting to find a way of expressing the meaning of the concept "constitution" in their own language, they just added the correct article (and altered the spelling) of the Spanish word "Constitution": "konstitutsion-kat". ${ }^{103}$

Once the translation had taken place and accepted by the respective communities, it was distributed as a book and a set of recordings. In addition to the seven translations (and the Spanish version), the book includes a glossary with Spanish legal terms translated into indigenous languages. The recordings contain enunciations of each article in the relevant indigenous language, followed by an explanation of the article (also in the indigenous language). Notwithstanding these results, Landaburu insists that the project must not be seen as an unqualified success; it proved too difficult, he suggests, to make durable bridges between such different cultures and world views. Perhaps, as expressed by $I k a$ linguist Rubiel Zalabata Torres, the one thing that they learnt from the process were the different ways in which two cultures "might conceive the world, how they have assimilated the reality of their surroundings, their ways of organising experiences and knowledge". ${ }^{104}$

\section{CONCLUSION}

This article briefly considered the role(s) played by linguistic and cultural diversity in the constitutions of Bolivia, Venezuela and Colombia, not only in terms of their content, but also the political and social processes that lead to their adoption and in the ways in which they were made accessible to non-Spanish speakers. That these constitutions gave juridical recognition to the diverse range of cultures in the region is not surprising. Indigenous groups had long been pushing for constitutional and cultural recognition through Central and South America. What is surprising is that, in a region as diverse and culturally rich as this one, composed of millions of human beings belonging to different cultures, communicating in hundreds of different languages, and characterised by ever changing constitutions, the recognition of language and cultural rights had come so late. The effect of these changes in the life, and quality of life, of indigenous peoples, remains to be seen.

102 In Spanish, hoja mayor de poder. Oróstegui Durán, ibid at 172.

103 Oróstegui Durán, ibid. There were other interesting translations of legal and political concepts. For example, the Kamsá, after expressing doubts as to who could be a sovereign people that at the same time has a duty to obey, translated the word "sovereignty" as "más wáman yentsangbe meresido y obenán", which means, "the most valuable right and power-of-doing of the people" (in Spanish, "el derecho y el poder hacer más valioso de la gente"). That same indigenous community translated the term "indigenous authority" as "kabengbe Iuarentsa Mandad", which means "governing ourselves and here" (in Spanish, "gobernante de nosotros mismos y de aquí mismo"). Jamioy Muchavisoy, above n 90, at 127-128.

104 Zalabata Torres, above n 93, at 140. 